\title{
PROBLEMÁTICA SOCIOAMBIENTAL NO LITORAL DO PARANÁ'.
}

\author{
Cláudio Jesus de Oliveira Esteves ${ }^{2}$
}

O litoral paranaense apresenta parte da sua área legalmente destinada à conservação do ambiente na forma de Unidades de Conservação. Ao mesmo tempo, observam-se problemas sociais e ambientais, relacionados às atividades econômicas e aos processos de ocupação, destacando-se, entre outras, as seguintes situações: a) A relação entre o uso dos recursos naturais, a conservação ambiental e as condições sociais, nos municípios que apresentam grandes áreas destinadas à conservação, como por exemplo Guaraqueçaba; b) Problemáticas sociais e ambientais decorrentes das atividades portuárias; c) Em Paranaguá a existência de áreas de ocupação em locais considerados de proteção permanente e problemas socioambientais como por exemplo o "lixão" do Embocuí; d) A questão do saneamento onde as piores situações (IBGE, 2000) ocorrem n llha do Mel (0\%), Pontal do Paraná com 1,87\% dos domicílios permanentes ligados à rede pública de esgotos, Guaraqueçaba $(5,38 \%)$, Morretes (7,10\%), Guaratuba e Matinhos (20,45\%); d) A ocupação de Guaratuba, Matinhos, Pontal do Paraná e llha do Mel, influenciada pela atividade turística/balneária e, em partes, direcionada pela lógica da especulação imobiliária, com vários casos de invasão em áreas de mangues, beiras de rios, zonas de marés, dunas, banhados. Devido ao caráter sazonal do turismo local, os problemas se agravam na "temporada" devido ao aumento do fluxo de turistas. A proposta de tese a ser apresentada terá como recorte espacial área do litoral paranaense (a ser definida), e abordará temática relacionada aos problemas socioambientais, resultantes da ocupação dessa região. O embasamento teórico-metodológico seguirá os princípios da geografia socioambiental, cujo campo de estudo analisa problemáticas decorrentes de situações conflituosas entre sociedade e natureza, e que resultam em situação de degradação social e/ou ambiental.

PALAVRAS-CHAVES: ocupação do litoral; degradação socioambiental; geografia socioambiental.

\footnotetext{
${ }^{1}$ Orientador: Prof. Dr. Francisco Mendonça

${ }^{2}$ Doutorando em Geografia (UFPR) - e-mail: claudiaojoe@ig.com.br
} 